Маријана Г. Митрић

Универзитет у Источном Сарајеву

Филозофски факултет Пале

Катедра за србистику

marijana.mitric@ffuis.edu.ba

https://doi.org/10.18485/ai_savremeni_roman.2020.ch5

821.163.41.09 Мартић В.

Оригинални научни рад

\title{
СЛИКА САРАЈЕВА У РОМАНУ ПУТ ЗА САНТА КЛАРУ ВИТОМИРА МАРТИТА
}

Предмет нашег истраживања јесте слика Сарајева у роману Пут за Санта Клару В. Мартића. Град у овом роману је не само позорница на којој се одвија радња романа већ је и пресудан чинилац у обликовању карактера и судбина ликова. Радња романа већим дијелом смјештена је у 70-те и 80-те године минулог вијека, мада Пут y Санта Клару захвата знатно шири временски оквир (Други свјетски рат, грађански рат 90-их). Прича о граду испричана је са дистанце. Наиме, наратор је због ратних сукоба присиљен да заувијек напусти родни град. Слику града, његово лице и наличје, сагледаћемо из визуре наратора који је уједно и приповједач потресних животних прича, али и самог бића града.

Кључне ријечи: роман, град, Сарајево, рат, наратор, стварносна проза, сказ, лајтмотив

Роман Витомира Мартића ${ }^{14}$ Пут за Санта Клару

14 Рођен је 21.3.1964. године у Сарајеву. У родном граду завршио је Другу гимназију, а затим Факултет физичке културе. Активно се бавио боксом девет година. Од 1994. године живи у Гетеборгу гдје је објавио и прве романе на шведском језику 1997. године - Лутке и сјене и Реквијем за губитнике. Слиједе рома- 
објављен је 2002. године код два издавача - Народне књиге из Београда и Завода за уџбенике и наставна средства из тада Српског Сарајева. ${ }^{15}$ Исте године овај роман нашао се у ужем избору за Нинову књижевну награду. Иван Негришорац, члан жирија, у тексту Млади романсијери и ратни кошмар Мартићев првенац на српском језику оцјењује као ,једно драго освежење српске књижевне сцене“ (2004: 156). Интересовање читалачке публике и данас као и те 2002. године за Пут у Санта Клару је велико. ${ }^{16}$ Доказ томе је и чињеница да је на Међународном сајму књига у Београду 2019. године роман поново представљен на штанду Завода за уџбенике из Источног Сарајева. Уз то треба нагласити да је и преведен на седам свјетских језика.

Међутим, роман Пут за Санта Клару је до данас у научној јавности остао на маргини проучавања, што је један од разлога нашег научног интересовања за њега. Други и много важнији разлог истакнут је у самом наслову рада. Наиме, ријеч је о слици Сарајева у савременом српском роману. Крајем XX и у првим деценијама XXI вијека низ истакнутих српских романсијера своје стваралаштво везује управо за овај град. Поменућемо само неке од њих: Момо Капор (Последюи лет за

ни на српском језику Пут за Санта Клару (2002) и Иза зидина (2009). Снимио је и документарни филм Пут за Санта Клару који је 2017. представљен на Филмском фестивалу у Сарајеву, а затим и на фестивалима у Хавани (2017) и Њу Делхију (2018).

15 За потребе рада користили смо издање Завода за уџбенике и наставна средства.

16 Истина, интересовање читалачке публике није условљено само књижевним вриједностима романа. Наиме, аутор је широј јавности познат због неколико ТВ гостовања, нпр. у емисији Миломира Марића Голи живот, у којима се врло духовито представио као пропали боксер, коцкар, „опасни момак“ и „страх и трепет за сарајевске мангупе и криминалце“. 
Сарајево, 1995; Хроника изгубљеног града, 1996; Чувар адресе, 2000, Сарајевске приче, 2000. и др.), Владимир Кецмановић (Ton је био врео, 2008; Осама, 2015), Бранко Брђанин Бајовић (Сила, 2010; Бестјелесна, 2013; Сарајево, Sarajevo, 2014; Архистратиг, чиноначалник, 2015), Саша Кнежевић (Откуд памет оном ко је нема, 2013; У сјећану на заборав, 2015), Драган Тепавчевић (Град за незбринуту дјеиу, 2015) и други. Овако паушалан списак аутора и наслова романа наводи на помисао да је Сарајево крајем XX и почетком XXI вијека постало инспиративно првенствено захваљујући немилим догађајима у Босни и Херцеговини, прије свега грађанском рату и егзодусу Срба из Сарајева. Истина, већина поменутих аутора не заобилази тему распада заједничке југословенске државе, а неки од поменутих романа као примарну имају управо ту тему. Међутим, чињеница да су о овом граду своја најзначајнија дјела написали великани Иво Андрић, Меша Селимовић, Исак Самоковлија и други демантује олако донесену претпоставку, те заједно са Џевадом Карахасаном закључујемо: „О том граду је, наиме, написано толико сјајне прозе колико није написано о многим великим градовима, тако да се нека веза између природе града, његовог платонског бића и књижевности која га приповиједа напросто мора претпоставити“ (2008: 167). Анализа, обимом невеликог романа Пут за Санта Клару, само је мали допринос освјетљавању природе града подно Требевића, специфичног по много чему у савременој српској књижевности.

Наиме, Сарајево је сусрет или судар Истока и Запада у срцу Европе. Све у њему и све око њега је толико замршено да се не може анализирати нити објаснити паровима бинарних опозиција село/град, свето/профано, рат/мир, некад/сад, богати/сиромашни, унутра/ вани како се ради кад се говори о другим градовима 
(Karahasan 2008: 163). Специфичног природног и географског положаја, у котлини, у магли, крваве историје, чудновате архитектуре, тамни вилајет - оно је и дом и уточиште и казамат, караказан, и Србима и Хрватима и Јеврејима и осталим. Свакодневица мултиетничког и мултикултуралног града сама по себи је довољно интригантна поетска тема. Ако је такав град уз то још и родни град ствараоца, показује се као немогуће одупријети се тако изазовној теми какво је овдје укратко описано Сарајево.

Витомир Мартић, чини нам се, и није имао амбицију да исприповиједа град, његову природу, иако признаје: „Волим да причам о предратном Сарајеву зато што је то прича о људима и времену који се сигурно никада неће поновити. Сарајево је тих осамдесетих година имало толико позитивне енергије као ниједан други град на свијету“" (Martić 2002). Настао по узору на роман Каd су иветале тикве Драгослава Михаиловића, Пут за Санта Клару је роман о одрастању Дача, младића са социјалне и културне маргине, који се због несрећних породичних околности почиње бавити ситним криминалом и стицајем околности нађе у Шведској у тренутку избијања грађанског рата у Босни и Херцеговини. Роман свакако није аутобиографски, иако је испричан у првом лицу, мада се животни пут приповједача и његова прича у многим битним појединостима поклапа са судбином свога аутора. Негришорац примјећује да је овај роман „прави наследник стварносне прозе, и то раних дела Драгослава Михаиловића, а местимице су препознатљиви и гласови Бранка Ћопића или Моме Капора“ (2004: 155-156). Сам аутор на питање новинара да ли његово дјело има сличности са раним радовима Драгослава Михаиловића одговара: „Има сличности. Михаиловићев роман Кад су иветале тикве је 
обиљежио моје сазријевање, пошто има доста сличности са мојим животним путем. У Михаиловићевом роману бивши боксер бјежи у Шведску. Кад сам 1994. године ишао у ту земљу, на путу до аеродрома купио сам ту књигу и са њом сам отишао из свег оног лудила“" (Martić 2009).

Не угледа се Мартић на Драгослава Михаиловића само у тематском смислу, већ и у погледу техника приповиједања. Као што већ рекосмо, он се одлучује за хомодијегетичког приповједача и технику сказа. Значи, причање је стилизовано као импровизација причаоца пред фиктивним слушаоцем. Приповиједање је драмски напето, осјећања се непосредно изражавају, описивања готово да и нема, јер углавном уступају мјесто наговјештајима, којима тек читаочев доживљај даје коначну форму. Технике су врло срећно одбране, у потпуности у складу са тематиком, међутим „језик овог романа је, хаотично груб и неуглађен, а понекад лишен и елементарне граматичке и правописне регуларности“ (Негришорац 2004: 156). Иако, по Негришорчевом суду језик романа „треба разумети и као прилог новом примитивизму у књижевности изразито урбаног карактера“ (2004: 156), не можемо се отети утиску да је управо тај и такав језик оно што читаоца омета да Пут за Санта Клару доживи као истинско умјетничко дјело.

Аутор није имао намјеру да „проституиш““ Сарајево, како сам каже у једном интервјуу ${ }^{17}$ и покушао је, питање је колико је то било могуће, да се одупре замкама патетике и избјегне ратну тему. Тако се Сарајево и

17 „Знате, нећу да ударим на сажаљење, патос или патетику. Јер, то је оно што је нагризло простор бивше Југославије. Нећу да проституишем име Сарајева, ни да купим поене на пропасти једног града ни да правим рекламу на биједи људи који тамо живе“" (Martić 2002). 
предратно и ратно у роману не јавља само као простор на ком се одвија радња, већ оно у тој радњи и учествује, одређује збивања и формира ликове. Пишући о Дачу и његовој породици и пријатељима, Мартић више несвјесно, него што осмишљава књижевни поступак, читаоцу „посредује атмосферу једног града, његово невидљиво, платонско биће, осјећање свијета које повезује све његове грађане, њихово осјећање самих себе и свога града“" (Karahasan 2008: 160).

С циљем да одреди угао под којим ће читалац посматрати догађаје и судбине ликова и да самом роману придода и одређену мисао дубину, на почетку романа стоји мото, Аристотелова мисао: „А онај ко не може живити у заједници или коме ништа није потребно јер је сам себи довољан није дио државе или је Бог или је звијер“ (Martić 2002: 3). Подсјетимо се, Аристотел је дефинисао ријеч полис у значењу мале државе или града. За њега сваки град представља заједништво, а такво заједништво тежи добру. Роман ће показати у коликој мјери се Сарајево може подвести под појам „заједништва које тежи добру“.

На самом почетку романа приповједач се оглашава са Кубе, гдје се по свему судећи добро снашао. Куба би требала бити, судећи по самом наслову романа, спасоносно одредиште или бар адекватна замјена за завичај и прошли живот, али она то по свему судећи није јер се приповједач осјећа изгнано и чезне за домовином: „Често мислим на то проклето Сарајево, а можда не бих требао. Лијепо ми је овдје, Куба је чудесна земља, а и људи су ме прихватили као свог. Вјерујте ми, уопште се не осјећам као странац“ (Martić 2002: 5). Љубав према Куби јавила се у јунаку још у раној младости, у вријеме болести Титове, када постају више него очигледне све мане друштвеног уређења тадашње Југославије. Дачова 
генерација „гута књиге“ о кубанској револуцији, славном комаданту Че Гевари и његовим герилцима, а сам јунак и тетовира његов лик на лијевој мишки, одмах изнад срца: „Ако је ико био прави, онда је то био Че Гевара. Он је био наш јунак“ (Martić 2002: 40). У ствари, Кубанци „имају нешто што су на Западу давно изгубили - душу“ (Martić 2002: 111), тако да је Куба можда и добра замјена за Шведску, али за Сарајево то никако није.

Исповијест која слиједи је свођење рачуна: „[...] договорим састанак са прошлошћу и поразговарамо. Ја онако тихо, лаганим мицањем усана, а она свемоћном тишином“ (Martić 2002: 6). Вријеме је да се у прошлости, у бившем животу, нађе одговор на питање шта га је довело до те и такве садашњости. Јунак покушава дефинисати сопствени идентитет, а спонтано уз то он дефинише и идентитет града који га је формирао.

Фигура оца пресудна је у формирању јунака романа, па овај покушавајући да открије своје мјесто у свијету, као почетну тачку приповиједања узима очево рођење 1933. године. Стева, касније прозван Кента, већ по рођењу остаје без мајке, а бригу о њему преузима кума Радица и сарајевска „улица“. И док му је отац Урош „за управљачем локомотиве тутњао кроз Југославију, коју су потресали убиство краља Александра, раднички штрајкови, лов на комунисте, у сјени великих свјетских догађаја гдје је један читав народ полудио за неким молером из Граца“ (Martić 2002: 9), Стева Кента, природно бистар и надарен дјечак, чувао је стражу „старијој раји“ из улице док су играли ајнц или бацали барбуте. Задатак му је био да купује цигаре, краде свијеће са Јеврејског гробља ако би се партија отегла до дубоко у ноћ или да отрчи на одређену адресу и донесе паре ономе ко губи. У Другом свјетском рату, Стева остаје без оца, 
кога убијају усташе, и без куме, а бригу о њему преузима Сеад Селимбашић звани Гроф, блудни син имућног Нусрет-бега. Уз Стевана Гроф спасава и Мориса, једног малог Јевреја са Враца који се отргнуо из колоне Јевреја које су усташе трпали у камионе. Ратне године проведене уз коцкара и бунтовника, касније партизана Сеада Селимбашића биле су пресудне у Стевановом одрастању. Већ тада, у најранијем дјетињству, Стеванов свијет постаје „шум карте која клизи по столу“ (Martić 2002: 14). На самом крају рата, Гроф гине. Иза њега остаје син Керим, који са Стеваном и Морисом постаје један од штићеника дома „Љубица Ивезић“ на Бјелавама гдје одрастају без љубави, без њежности уз лажно сажаљење:

„За празнике им ставе капе и црвене мараме, дају им по колач за ручак, доведу новинаре и фотографе и говоре нешто у стилу:

- Ми бринемо за дјецу палих бораца, и не само бораца, ми бринемо за сву нашу дјецу, они су наше сутра, наше највеће богатство - и онда збришу у лимузинама негдје на добру крканцију“ (Martić 2002: 29).

Уз приче готово па увијек „накресаног“ оца о Грофу, другарству у рату, никада о животу у дому, одрастао је Дача, као и потомци других штићеника дома за незбринуту дјецу на Кошевском брду. Доносимо обиман цитат из романа који на најбољи начин илуструје атмосферу у којој се формира јунакова личност:

„Крај гдје сам се родио и одрастао био је у то доба на злу гласу. Многи мангупи нису смјели навраћати на Кошевско брдо [...] А ни муријашима није било свеједно. [...] То наше насеље је било право радничко, са старим зградама склепаним на брзину послије „оног“ рата, са којих је отпадала фасада као са лињала кера длака. Изузетак је био пар кућа у Кордунској улици које су некако штрчале 
са својим прелијепим баштама. [...] Био је ту и парк са тобоганом који смо одвалили јер нам је сметао док смо, по цијели божји дан, пикали фудбал.

Тек почетком седамдесетих почеле су се градити вишеспратнице и са новим становницима који су се досељавали као да је почео расти и онај урбани дух краја. [...] Поред наше зграде у великом дворишту су биле још три такве идентичне зграде са малим једнособним становима, без купатила, са тушем у клозету, тако да је купање изискивало прави ритуал. Скученост се осјећала на сваком кораку. Само пар десетина метара од зграда налазила се хемијска фабрика „Босналијек“, у којој је радила моја мајка Даница, тако да не могу рећи да смо се надисали чистог ваздуха. Напротив, љети су из фабрике пуштали амонијак и још некакве отпатке у поток Сушицу па је цијели крај одвратно заударао, нешто налик на покварена јаја. Ето ту, сабити у раднички гето, збијени у на брзину склепаним зградама, живјели су другови из дома „Љубица Ивезић“ (Martić 2002: 33).

Кошевско брдо, тај смрдљиви раднички гето, за јунака романа је ипак својеврсна оаза, дом, наткриљен великом Штефином липом, која се у роману јавља као својеврсни лајтмотив. Липа, чији мирисни цвјетови посједују ублажавајућа својства, увијек се сматрала симболом пријатељства. Стичемо дојам да је овај простор издвојен из Сарајева, које је у свијести јунака опасан простор у коме владају нека друкчија правила. Развијени описи града изостају. Он је присутан само у запажањима типа „облаци се надвише над ионако црним Сарајевом“ (Martić 2002: 10), изгледа „јадно и суморно“, „мрак се надвио над Сарајевом“ (Martić 2002: 27), „зграде поред цесте дјеловале су сабласно, као да ће сваки час пустити пипке и зграбити нас“ (Martić 2002: 41), аветињски град. Сви поменути примјери алудирају на демонску природу града. 
С друге стране, живот на Кошеву се показује као једноставан ако се на вријеме науче одређена правила. Прво је да се мрзе цинкароши и друго „тотална послушност и респект према старијим мангупима из краја“" (Martić 2002: 33). И, да под таквим условима и правилима било би лако, можда чак и лијепо живјети, да родитељи јунака не носе трауматска искуства из рата и да се свакодневно не сусрећу са различитим видовима аномалија градског живота. Политичке и економске прилике се итекако одражавају на породични живот Кинезов стари Жарко је попио двије плате унапријед, Стеван се одао коцки и слично, јер управо они који су у рату највише изгубили, сирочићи из „Љубице Ивезић“, радници који су своје животе уградили у темеље социјализма себи и својој дјеци не могу да обезбиједе живот достојан живљења. Разрушени и поремећени породични односи јунака романа и његове пријатеље воде у ситни криминал, који они и не доживљавају као нешто негативно и лоше: „они дрпали од Дане и таквих ко она, ми опет узели од њих и 'поштено' вратили“ (Martić 2002: 38). У једној таквој акцији „поштеног враћања одузетог“, тачније пљачки локалног гранапа, Дачови пријатељи бивају ухваћени и завршавају у поправном дому. Дачо стицајем прилика, због упале слијепог цријева, у акцији не учествује.

Дачо, тек гимназијалац, настоји да породицу одржи на окупу, да надомјести мајци и сестри стално одсутног оца, покушава тог истог оца разумјети, али и живјети као и сви млади. Тренира бокс, „мува се“ по чувеним сарајевским клубовима „Слога“ и „Кактус“ и заљубљује у Александру, студенткињу глуме. Некако у исто вријеме Александра са породицом одлази у Шведску у потрази за бољим животом када и Стеван завршава у затвору. 
Наиме, Мустафа Хазнадаревић, син првоборца и министра, један од моћника у граду, готово недодирљив, од ране младости је заљубљен у Дачову мајку Дану. Управо он је примјер из кога се најбоље види по којим принципима и како се живи у Сарајеву 70-их и 80-их година XX вијека. Политички утицај и позиција користе се само у личне сврхе. Стевану шеф намјешта аферу крађе како би га затворском казном удаљио од породице, а за узврат од Мустафе добија љубавницу и стан. Од дјетињства порочан и слаб, Стеван једино у коцки види излаз те на исту ставља своју жену и дјецу и губи. Једино што му преостаје је да оде, тачније нестане из Сарајева.

Без пријатеља, дјевојке, циља, јунак романа у Сарајеву не може да нађе своје мјесто те креће у потрагу за оцем. Путем којим га воде очеви трагови у европским коцкарским круговима, он стиже у Палмеову Шведску, која у том тренутку за њега представља обећану земљу - земљу једнакости и правде, земљу у којој својим радом и трудом може обезбиједити егзистенцију, помоћи породици, пријатељима. И оном тренутку кад јунак помисли да је на правом мјесту и у право вријеме, прилике у Шведској се мијењају, а почиње и рат у Босни и Херцеговини:

„Кад је запуцало у Сарајеву, нисам се тријезнио мјесец дана. Гледам у почетку оне шведске вијести и сваки пут изнова осјетим како ми се свијет руши. Као да и сам нестајем па поново оживљавам. Чини ми се да сам умирао три пута дневно“" (Martić 2002: 98-99).

Пут за Санта Клару је прије свега роман о одрастању и породични роман, али он тематизује и још једну велику универзалну причу - причу о бездомности и искоријењености или простије речено избјеглички 
синдром. У оном тренутку када схвати да повратка у Сарајево нема у Дачу се буди носталгија, „осјећај немоћи јада који носиш са собом ко свој излизани капут“ (Martić 2002: 100). Из дубина прошлости израња она Штефина липа, симбол заједништва и породичне топлине:

„Пало вече. Стојим на прозору, крњави мјесец извирује, а кроз магличасти ваздух видим како јој се њишу гране. Лишће трепери на вјетру а њен мирис шири ми груди. И цијели крај мирише од Штефине липе. А на бетонском зиду поред саме цесте младићи и дјевојке пјевају уз гитару.

Желио сам тада, у мраку моје собе на Шархолмену, да та слика никад не нестане. Имао сам осјећај да је оно тамо био стварни живот, а да је ово сада неки туђи, мени поклоњен“" (наше подвлачење) (Martić 2002: 101).

Та нагонска потреба за нечим својим, нечим што само њему припада, за градом, који ма какав да је јунаку пружа осјећај стварног живота, оног живота у коме он истински учествује и осјећај припадања некој заједници - „Какво год, то је ипак некад било моје. Ружно, прљаво, добро, лоше, али је било моје“ (Martić 2002: 103) - води га у Сарајево одмах по завршетку ратних сукоба.

Међутим, поратно Сарајево показује Дачу једно потпуно ново лице, у ствари то и није ново лице града, већ неки потпуно нови град. „Удишем ваздух, осјетим није исти као прије“ (Martić 2002: 103). На улици не сусреће ни једно познато лице, а тек на прагу рођене куће, јунак схвата колико је „туђ и стран самом себи и људима око мене“ (Martić 2002: 107).

У ствари Сарајево тек у том тренутку јунаку открива своје право лице, своју демонску природу. То је град 
који прождире или тјера далеко своју дјецу, да би их и тамо на другом крају свијета, чак у Санта Клари, у сну посјећивало и прогонило. Андрић је без сумње на најбољи могући начин осјетио и насликао природу Сaрајева, а читав низ стваралаца раније поменутих којима се придружује и Витомир Мартић тој слици демонског града додаје по једну нијансу, можда малу, али у свеукупности тог мозаика, никако неважну.

\section{Извори и литература}

Jeremić, Ljubiša. Proza novog stila. Beograd: Prosveta, 1978.

Karahasan, Dževad. „Pripovijedati grad“. Sarajevske sveske, br. 21/22, 2008, 156-179.

Martić, Vitomir. Put za Santa Klaru. Srpsko Sarajevo: Zavod za udžbenike i nastavna sredstva, 2002.

Martić, Vitomir. „Zaboravili smo šta je iskrenost“. (razgovor vodila Tatjana Nježić), B92, 24.6.2002. Veb. 21.9.2019.

Martić, Vitomir. „Pisanje u bokserskim rukavicama“. (razgovor vodio DejanVujanić). Glas srpske, 12.5.2009. Veb. 21.9.2019.

Негришорац, Иван. „Млади романсијери и ратни кошмар“. Кораци: часопис за кюижевност, уметност и културу, год. 37, књ. 34, цв. 1/2, 2004, 153-158.

Marijana G. Mitrić

\section{THE IMAGE OF SARAJEVO IN THE NOVEL ROAD TO SANTA CLARA BY VITOMIR MARTIĆ}

\section{Summary}

In the focus of this research was the image of Sarajevo in the novel Road to Santa Clara, written by Vitomir Martić. The novel 
has been published in 2002, but until today it remained on the margins of researches. Sarajevo, a place of meeting and conflict between east and west, i.e. different religions - Christianity, Islam, Judaism; two scripts - Cyrillic and Latin; economic systems - communism and capitalism; old and new way of life very frequently serves as inspiration for contemporary Serbian novelists (M. Kapor, V. Kecmanović, B. Brđanin Bajović, S. Knežević, D. Tepavčević etc.). The writer himself is born in Sarajevo, so it is very natural that such a city is a stage for his novel's plot. However, the city in Martić's novel is more than a stage, it is about the same time a crucial factor in shaping characters and their destinies. The plot is mainly related to $1980 \mathrm{~s}$, but Road to Santa Clara incorporates a wider temporal framework (World War II, civil warduring 1990s). The story about the city has been told from distance. Namely, the narrator is one of those who were forced to leave the city duet o armed conflict. Taking into account that the city is imposed as the main hero with in the novel, we have perceived the complete image of its both face and reverse form the narrator's point of view, who is at about the same time a story teller of shattering life stories and the very soul of the city.

Key words: novel, city, Sarajevo, war, narrator, reality prose, fairy tale, leitmotif 